\title{
Pengaruh Terapi Relaksasi Nafas Dalam dan Murottal terhadap Tekanan Darah
}

\section{The Influence of Deep Breath Relaxation Therapy and Murottal on Blood Pressure}

\author{
Erlita Kundartiari $^{1 *}$, Sri Nur Hartiningsih ${ }^{2}$ \\ 1. STIKes Surya Global Yogyakarta, Indonesia \\ 2. STIKes Surya Global Yogyakarta, Indonesia \\ *Email Korespondensi: widyaerlita7@gmail.com
}

\begin{abstract}
Abstrak
Latar belakang: Penyakit yang sering dijumpai pada lanjut usia (lansia) adalah hipertensi. Prevalensi hipertensi dalam RISKESDAS tahun 2018 sebanyak 34,1\% didasarkan pada pengukuran tekanan darah pada usia $\geq 18$ tahun. Pengontrolan tekanan darah sangat diperlukan bagi penderita. Terapi yang dapat dilakukan adalah terapi relaksasi nafas dalam serta terapi murottal yang tidak menimbulkan efek samping bagi penderitanya.

Tujuan: Untuk mengetahui apakah terdapat pengaruh terapi relaksasi nafas dalam serta murottal terhadap tekanan darah pada penderita hipertensi di Posyandu Lansia Pisang Mas Pandak Bantul Yogyakarta.

Metode: Jenis penelitian adalah kuantitatif dengan rancangan Quasi eksperimental design dengan non equivalent (pretest dan posttest) control group. Jumlah sampel penelitian sebanyak 27 responden yaitu 14 responden kelompok intervensi diberikan terapi relaksasi nafas dalam dan murottal, 13 responden adalah kelompok kontrol diberikan murottal yang diambil menggunakan teknik purposive sampling, yaitu dengan dikenakannya kriteria inklusi dan eksklusi pada populasi penelitian.

Hasil: Hasil uji normalitas data menggunakan skala kurtosis menunjukkan data berdistribusi normal, maka menggunakan uji parametrik. Analisa data dengan paired t-test dan independent t-test. Berdasarkan pengujian paired t-test bahwa terdapat perbedaan tekanan darah sebelum dan sesudah perlakuan pada kelompok intervensi ( $p$ value $0,003<0,05$ ) pada kelompok kontrol ( $p$ value $0,006<0,05)$. Hasil uji independent t-test menunjukkan tidak terdapat perbedaan rerata penurunan tekanan darah sistol maupun diastol antara kelompok intervensi dan kelompok kontrol dengan nilai $p$ value $>0,05$.

Kesimpulan: Terdapat pengaruh terapi relaksasi nafas dalam dan murottal menurunkan tekanan darah sistol dan diastol penderita hipertensi di Posyandu Lansia Pisang Mas Pandak Bantul Yogyakarta.
\end{abstract}

Kata kunci: Hipertensi; Lansia; Murottal; Relaksasi Nafas Dalam

\begin{abstract}
Background: The most common disease in the elderly are hypertension. The prevalence of hypertension in RISKESDAS in 2018 was 34,1\% based on blood pressure measurements at age $\geq 18$ years. Blood pressure control is very necessary for sufferers. Therapy that can be done is deep breath relaxation therapy and murottal therapy which do not cause side effects for the sufferer.
\end{abstract}


Objective: To find out whether there is an effect of deep breathing and murottal relaxation therapy on blood pressure in hypertension at the Posyandu Lansia Pisang Mas Pandak Bantul Yogyakarta.

determine the influence of deep breath relaxation therapy and murottal on blood pressure in patients with hypertension in Posyandu Lansia Pisang Mas Pandak Bantul Yogyakarta.

Method: This type of research is quantitative with a Quasi-experimental design with a nonequivalent (pre-test and post-test) control group. The total sample of the study was 27 respondents, namely 14 respondents in the intervention group who were given deep breath relaxation and murottal therapy, 13 respondents were the control group who were given murottal which were taken using purposive sampling technique, namely by applying inclusion and exclusion criteria to the study population.

Result: results of the data normality test using the kurtosis scale show the data is normally distributed, so using the parametric test. Data analysis using paired t-test and independent $t$ test. Based on the paired t-test that there were differences in blood pressure before and after treatment in the intervention group ( $p$-value 0,003<0,05) in the control group ( $p$-value $0,006<0,05$. The results of the independent t-test showed that there was no difference in the mean reduction in systolic and diastolic blood pressure between the intervention group and the control group with a p-value >0,05.

Conclusion: There is an effect of deep breathing and murottal relaxation therapy to reduce systolic and diastolic blood pressure in hypertensive patients in Posyandu Lansia Pisang Mas Pandak Bantul Yogyakarta

Keywords: Deep Breath Relaxation; Elderly; Hypertension; Murottal

\section{PENDAHULUAN}

Hipertensi atau yang lebih sering dikenal dengan tekanan darah tinggi merupakan salah satu penyakit kardiovaskuler yang banyak terjadi pada lanjut usia (lansia) dan karena usia lanjut mereka lebih mungkin mengalami komplikasi sekunder sampai kenaikan tekanan kronis(2). Pada saat usia lanjut, organ vital seperti otak sangat memerlukan suplai darah yang optimal, namun semakin bertambahnya usia seseorang akan menyebabkan kondisi sistem kardiovaskuler mengalami penurunan karena terjadinya arterosklerosis yang akan mengakibatkan peningkatan tekanan darah. Hal tersebut menjadi alasan bahwa lanjut usia memiliki resiko yang lebih besar menderita penyakit hipertensi(3). National Health Interview Survey menjelaskan bahwa prevalensi hipertensi pada lansia untuk laki-laki sebesar 54\% sedangkan untuk perempuan sebesar 57\%. Penyakit hipertensi memiliki prevalensi tertinggi bila dibandingkan dengan penyakit lainnya(4). Di negara Indonesia sendiri, memiliki prevalensi hipertensi sebesaar 45,9\% pada usia 55-64 tahun, sebesar 57,6\% pada usia 65-74 tahun, dan sebesar 63,8\% pada usia $>75$ tahun(3). Prevalensi hipertensi dalam RISKESDAS tahun 2018 sebanyak $34,1 \%$ didasarkan pada pengukuran tekanan darah pada usia $\geq 18$ tahun(1).

Data Dinas Kesehatan DIY 2019 menunjukkan kejadian tekanan darah tinggi di provinsi DIY sebesar $32,86 \%$ didasarkan pada pengukuran penduduk pada usia $\geq 18$ tahun. Prevalensi tertinggi di Gunungkidul (39,25\%), diikuti Kulonprogo (34,7\%), Sleman (32,01\%), Bantul $(29,89 \%)$, dan Yogyakarta (29,28\%)(5). Kabupaten Bantul menempati urutan ke-4 dalam kasus kejadian hipertensi. Selain itu, umur Harapan Hidup (UUH) waktu lahir di kabupaten Bantul yang tercatat dalam badan pusat statistik menunjukkan peningkatan, yaitu sebanyak 73.56 tahun(6). Kasus kejadian penyakit hipertensi di kabupaten Bantul tercatat dalam data Dinas Kesehatan Kabupaten Bantul adalah sebanyak 10.237 dengan persentase 1,38 \%(7).

Hipertensi jika tidak dikontrol akan menyebabkan komplikasi seperti gagal ginjal, stroke, dan koroner(8). Penatalaksanaan hipertensi bertujuan untuk menurunkan resiko 
serangan jantung, gagal jantung, dan stroke yang disebabkan oleh hipertensi(9). Penatalaksanaan hipertensi dikelompokkan menjadi 2 jenis yaitu farmakologis dan nonfarmakologis. Penatalaksanaan secara nonfarmakologis dapat digunakan oleh penderita hipertensi dalam jagka waktu yang cukup panjang, mengingat bahwa tindakan ini tidak menimbulkan efek samping bagi yang mengaplikasikannya dalam pengontrolan tekanan darah selain terapi obat yang sudah didapatkan oleh penderita dari dokter selama melakukan pemeriksaan. Terapi yang tidak menimbulkan efek samping tersebut adalah salah satunya terapi relaksasi nafas dalam dan murottal.

Penelitian yang dilakukan oleh Fitriani, 2016 tentang pengaruh terapi relaksasi nafas dalam terhadap tekanan darah pada lansia penderita hipertensi di posyandu lansia pringgolayan Rt VII Banguntapan Bantul Yogyakarta. Metode yang digunakan dalam penelitiannya adalah Quasi experiment dan rancangan yang digunakan adalah Nonrandomized pretest-posttest with control group design. Hasil penelitiannya diketahui bahwa terapi relaksasi nafas dalam yang diberikan kepada responden dapat mempengaruhi tekanan darah pada lansia yang mengalami hipertensi, dengan reaksi yang diberikan yaitu responden merasakan keadaan rileks, yang dapat mengurangi keluhan-keluhan pusing, mual dan sakit pada bagian kepala belakang atau tengkuk dan tidak menimbulkan efek samping(10). Persamaan dalam penelitian ini terletak pada responden yang digunakan dalam penelitian, serta variabel dependen penelitian. Sedangkan perbedaannya terletak pada variabel independen, yang mana penelitian sebelumnya memberikan terapi relaksasi nafas untuk melihat apakah terapi tersebut dapat memberikan pengaruh terhadap penurunan tekanan darah pada lanjut usia yang mengalami tekanan darah tinggi, sedangkan penelitian sekarang menambahkan terapi murottal disamping terapi tersebut.

Penelitian yang dilakukan Despitasari, L. (2019) tentang pengaruh mendengarkan AlQur'an terhadap perubahan tekanan darah pada lansia penderita hipertensi diwilayah kerja puskesmas andalas Padang tahun 2018, hasilnya bahwa tekanan darah sistol penderita hipertensi mengalami penurunan yaitu $149,27 \mathrm{mmHg}$ dan tekanan darah diastol mengalami penurunan $81 \mathrm{mmHg}$ setelah penderita hipertensi mendengarkan bacaan Al-Qur'an selama 7 hari berturut-turut. Metode yang digunakan adalah quasi eksperimen dengan desain one group pretest-posttest design(11). Perbedaan dari penelitian ini dan penelitian sekarang yaitu terletak pada variabel independen, dimana penelitian ini hanya memberikan kepada lansia bacaan AlQur'an selama 20 menit dengan frekuensi satu kali sehari selama satu minggu, sedangkan penelitian sekarang memberikan bacaan Al-Qur'an surat Ar-Rahman ayat 1-78 yang diperdengarkan menggunakan pengeras suara yang dibacakan oleh Ahmad Saud selama 13 menit 54 detik dengan frekuensi waktu satu kali sehari dalam 4 hari berturut-turut. Pengukuran tekanan darah dilakukan sebelum terapi diberikan dan diukur kembali saat setelah terapi diberikan.

Penelitian lain juga dilakukan oleh Aziza, C. N. (2019) yang mengetahui bahwa murottal Al-Qur'an selain dapat menurunkan tekanan darah bagi penderitanya, juga dapat mengendalikan emosi (anger management). Desain penelitian menggunakan pretest-posttest with two group design dengan metode quasi-eksperimental. Hasil yang diperoleh bahwa setelah mendengarkan murottal Al-Qur'an, responden merasa nyaman dan tenang. Saat kondisi tersebut, maka reponden dapat mengendalikan emosi yang dirasakan yang dapat mempengaruhi penurunan tekanan darah(12). Dalam penelitian ini, diberikan bacaan surat ArRahman dengan durasi waktu 10-15 menit, frekuensi 2 hari sekali pada waktu sore hari selama 1 minggu. Sedangkan pada penelitian sekarang, peneliti memberikan terapi kombinasi relaksasi nafas dalam serta murottal Al-Qur'an Ar-Rahman. Terapi relaksasi nafas dalam diberikan selama 15 menit, setelah itu diberikan bacaan surat Ar-Rahman yang dibacakan Ahmad Saud dengan durasi 13 menit 54 detik, sebelumnya diukur tekanan darah lansia dan 
diukur kembali setelah kedua terapi diberikan. Kedua perlakuan tersebut diberikan selama 4 hari berturut-turut, dengan cara responden dikumpulkan secara bersamaan dirumah pak dukuh. Responden dikondisikan dalam keadaan duduk dan melakukan terapi relaksasi nafas dalam kemudian dilanjutkan dengan mendengarkan MP3 Q.S Ar-Rahman dengan pengeras suara.

Penelitian Agustin, W. R., Rosalina, S., Ardiani, N. D., \& Safitri, W. (2019) memberikan perlakuan relaksasi genggam jari dan nafas dalam untuk menurunakan tekanan darah pada penderita hipertensi wilayah kerja Puskesmas Kartasura. Diketahui bahwa kedua terapi tersebut dapat digunakan untuk mencegah terjadinya penyakit hipertensi. Desain penelitian menggunakan one group Pre-Post test design dengan metode Pre Experimental(13). Perbedaannya terletak pada variabel independen, dimana dalam penelitian ini memberikan 2 terapi sekaligus yaitu berupa terapi genggam jari dan nafas dalam, yang diberikan sebanyak 1 kali, setelah 24 jam dari pemberian kedua terapi tersebut, maka tekanan darah penderita hipertensi diukur, sedangkan penelitian sekarang menggabungkan terapi relaksasi nafas dalam dengan murottal Al-Qur'an Ar-Rahman dan segera dilakukan pengukuran tekanan darahnya (posttest).

Dr. Al Qadhi melakukan penelitian diklinik besar Florida Amerika Serikat, menemukan hal bahwa hanya dengan mendengarkan bacaan-bacaan surat Al-Qur'an memberikan banyak dampak positif bagi yang mendengarnya, selain itu dengan mendengarkan bacaan Al-Qur'an 97\% akan menimbulkan ketenangan jiwa dan penyembuhan penyakit. Dampak umum yang diberikan setelah mendengarkan bacaan Al-Qur'an yaitu berupa perubahan psikologis yaitu penurunan depresi, kesedihan yang akan berpengaruh terhadap tekanan darah, irama jantung, serta kekuatan otot(14).

Dari studi pendahuluan yang telah dilakukan oleh peneliti pada 24 oktober 2019 yang mewawancarai 10 lansia dengan hipertensi yang berkunjung ke posyandu lansia pisang mas Pandak Bantul Yogyakarta, ada beberapa lansia yang mengeluh pusing, ngantuk, kesemutan, kaku pada area leher, namun ada juga yag tidak merasakan keluhan sama sekali. Saat keluhan itu dirasakan, mereka hanya memeriksakan diri pada saat posyandu lansia dan kemudian mendapatkan obat untuk mengurangi keluhan-keluhan yang dirasakan, kemudian mereka hanya istirahat untuk mengurangi keluhannya. Selain itu, beberapa lansia mengkonsumsi jamu jawa yang dibeli dipasaran untuk mengurangi keluhan-keluhan yang dirasakan. Mereka mengatakan sudah lama mengalami penyakit hipertensi yaitu sekitar kurang lebih 1,5 tahun. Dari 10 lansia tersebut, mengatakan bahwa mereka belum pernah melakukan/mendapatkan Terapi bacaan surat Ar-Rahman dan nafas dalam untuk mengontrol tekanan darah mereka dan tidak memberikan dampak lain, serta memberikan pengurangan keluhan tekanan darah tinggi yang dirasakan.

\section{METODE}

Penelitian ini telah dilakukan pada tanggal 4-7 Maret 2019 diposyandu lansia pisang mas Pandak Bantul Yogyakarta dengan nomor etik: 050.3/FIKES/PL/II/2020. Jenis penelitian kuantitatif dengan rancangan penelitian Quasi eksperimental design dengan non equivalent (pretest dan posttest) control group, yaitu rancangan yang digunakan untuk melihat hubungan sebab akibat dengan menggunakan kelompok kontrol disamping kelompok eksperimental, dengan purposive sampling sebagai tekhnik dalam pengambilan sampel. kriteria inklusi yang dikenakan dalam penelitian ini adalah lanjut usia dengan batas usia $\geq 60$ tahun, responden dengan agama Islam, hasil ukur tekanan darah sistol berdasarkan pencatatan saat posyandu lansia $\geq 140 \mathrm{mmHg}$ dan tekanan darah diastol $\geq 74 \mathrm{mmHg}$, bersedia menjadi responden dengan menandatangani informed consent. Setelah dikenakan kriteria inklusi dan eksklusi, maka didapatkan jumlah sampel penelitian sebanyak 27 lansia, dengan 14 lansia 
sebagai kelompok intervensi yang mendapatkan terapi relaksasi nafas dalam dan murottal, 13 lansia lainnya adalah kelompok kontrol yang mendapatkan terapi murottal. Tidak terdapat responden drop out dalam penelitian. Terapi relaksasi nafas dalam diberikan selama 15 menit, sedangkan terapi murottal diberikan selama 13 menit 54 detik yang dibacakan oleh Ahmad Saud. Karakteristik surat Ar-Rahman Ahmad Saud ini telah divalidasi dilaboratorium seni Fakultas Budaya dan Seni Universitas Negeri Semarang, dimana akan memberikan kualitas bagi yang mendengarnya dan memiliki efek terapeutik. Kedua perlakuan diberikan 5-7 jam setelah responden meminum obat antihipertensi. Perlakuan diberikan selama 4 hari berturutturut.

Alat-alat yang diperlukan dalam penelitian adalah berupa lembar observasi untuk mencatat hasil pengukuran tekanan darah serta sphygnomanometer yang sudah dilakukan uji kalibrasi di PT Adi Multi Kalibrasi dengan sertifikat kalibrasi no: 3058/AMK/XII/2019. Parameter yang diamati dalam penelitian ini adalah variabel tekanan darah yang diukur sebelum dan sesudah diberikan perlakuan kepada masing-masing responden. Sebelum dilakukan uji hipotesis terlebih dahulu dilakukan uji normalitas data menggunakan skala kurtosis dengan hasil data berdistribusi normal $p$ value -2 s.d 2. Data dianalisis secara deskriptif (distribusi dan persentase), analisis bivariat menggunakan paired t-test dengan hasil $p$ value $<0,05$ dan independent $t$-test dengan hasil nilai $p$ value $>0,05$.

\section{HASIL}

1. Analisa Univariat

a. Karakteristik Responden

Hasil penelitian yang sudah dilakukan mendapatkan hasil persentase jenis kelamin, umur, pendidikan, lama menderita hipertensi sampel penelitian.

Tabel 1. Jenis Kelamin, Umur, Pendidikan, Lama Hipertensi Sampel Penelitian

\begin{tabular}{|c|c|c|}
\hline Karakteristik Responden & $\begin{array}{l}\text { Kel. Intervensi } \\
\quad(n=14)\end{array}$ & $\begin{array}{l}\text { Kel. Kontrol } \\
(\mathrm{n}=13)\end{array}$ \\
\hline \multicolumn{3}{|l|}{ Jenis kelamin (n, \%) } \\
\hline Laki-laki & $3(21,4 \%)$ & $1(7,7 \%)$ \\
\hline Perempuan & $11(78,6 \%)$ & $12(92,3 \%)$ \\
\hline \multicolumn{3}{|l|}{$\operatorname{Umur}(\mathbf{n}, \%)$} \\
\hline 60-70 tahun & $7(50,0 \%)$ & $8(61,5 \%)$ \\
\hline 71-80 tahun & $3(21,4 \%)$ & $3(23,1 \%)$ \\
\hline 81-90 tahun & $4(28,6 \%)$ & 0 \\
\hline 91-100 tahun & 0 & $2(15,4 \%)$ \\
\hline \multicolumn{3}{|l|}{ Pendidikan (n, \%) } \\
\hline Tidak sekolah & $8(57,1 \%)$ & $9(69,2 \%)$ \\
\hline SD & $6(42,9 \%)$ & $4(30,8 \%)$ \\
\hline SMP & 0 & 0 \\
\hline \multicolumn{3}{|l|}{ Lama hipertensi (n, \%) } \\
\hline 1-6 bulan & $2(14,3 \%)$ & 0 \\
\hline 1-2 tahun & $12(85,7 \%)$ & $10(76,9 \%)$ \\
\hline 3-4 tahun & 0 & $3(23,1 \%)$ \\
\hline
\end{tabular}

Tabel 1 diketahui bahwa lanjut usia perempuan memiliki jumlah yang lebih besar bila dibandingkan dengan lanjut usia laki-laki, 11 lansia $(78,6 \%)$ kelompok intervensi dan sebanyak 12 lansia (92,3\%) kelompok kontrol. Sedangkan umur lansia sebagian besar berada dalam rentang usia 60-70 tahun, yaitu 7 lansia (50\%) pada kelompok intervensi dan sebanyak 8 lansia $(61,5 \%)$ pada kelompok kontrol. selain itu, tingkat pendidikan lansia sebagian besar 
dari mereka tidak sekolah, yaitu sebanyak 8 lansia $(57,1 \%)$ pada kelompok intervensi dan 9 lansia $(69,2 \%)$ pada kelompok kontrol. Sedangkan, untuk lama menderita hipertensi sebagian besar selama 1-2 tahun, 12 responden (85,7\%) kelompok intervensi dan 10 responden $(76,9 \%)$ kelompok kontrol.

\section{b. Perubahan Tekanan Darah Sistolik}

Hasil data perubahan tekanan darah sistolik kelompok intervensi dan kelompok kontrol dari hari ke-1 sampai dengan hari ke-4 penelitian.

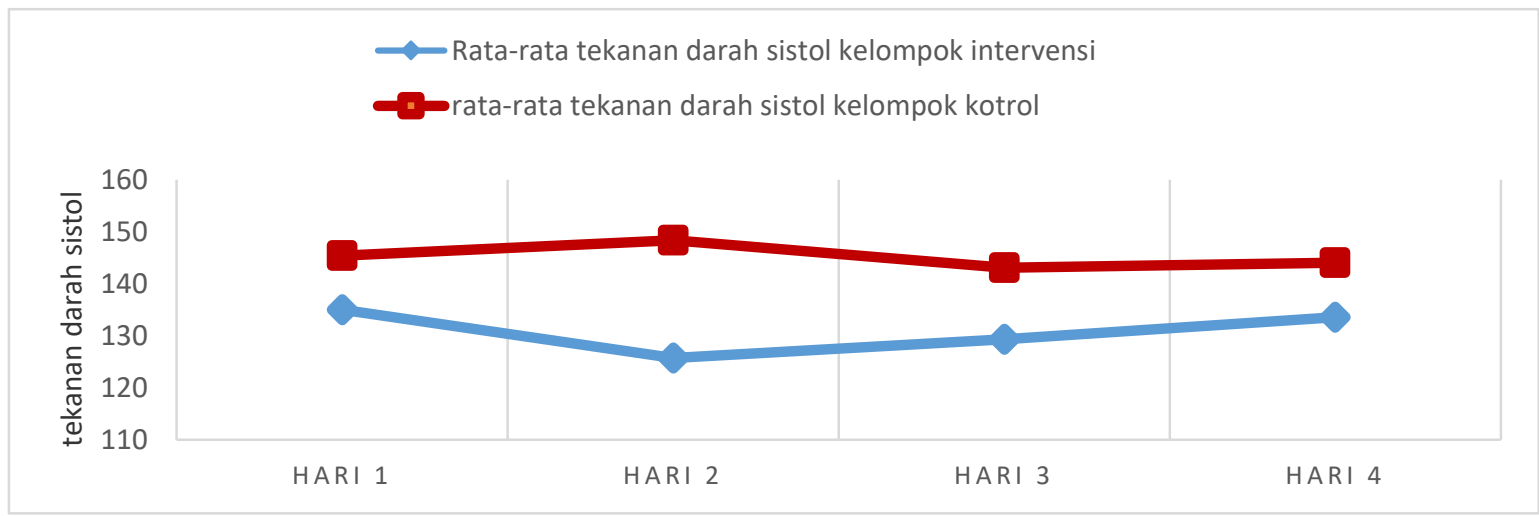

\section{Grafik 1. Perubahan Tekanan Darah Sistolik Kelompok Intervensi dan Kelompok Kontrol Hari 1-4 Penelitian}

Grafik 1 diketahui rata-rata tekanan darah pada hari pertama pemeriksaan pada kelompok intervensi adalah $135 \mathrm{mmHg}$, sedangkan untuk kelompok kontrol 145,38 $\mathrm{mmHg}$. Rerata tersebut terjadi pada hari ke-3 penelitian, sedangkan untuk kelompok intervensi, penurunan tekanan darah terjadi di hari ke-2 penelitian. Sedangkan di hari ke-2 dan ke-4 perlakuan pada kelompok kontrol, terdapat peningkatan rata-rata tekanan darah sistol, dan pada kelompok intervensi terjadi peningkatan rata-rata tekanan darah sistol pada hari ke-3 dan ke-4 penelitian.

c. Perubahan Tekanan Darah Diastol

Hasil data perubahan tekanan darah diastol untuk kelompok intervensi dan kelompok kontrol dari hari ke-1 sampai dengan hari ke-4 penelitian.

$\leadsto$ Rata-rata tekanan darah distol kelompok intervensi

Rata-rata tekanan darah distol kelompok kontro

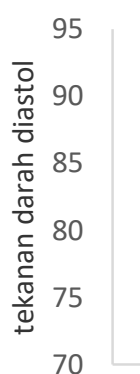

Grafik 2. Perubahan Tekanan Darah Diastolik Kelompok Intervensi dan Kelompok Kontrol Hari 1-4 Penelitian

Grafik 2 diketahui tekanan darah diastol hari pertama penelitian pada kelompok intervensi adalah 83,57 $\mathrm{mmHg}$, sedangkan untuk kelompok kontrol 88,46 $\mathrm{mmHg}$. Rerata 
tersebut pada hari ke-3 penelitian, sedangkan untuk kelompok intervensi, penurunan tekanan darah terjadi di hari ke-2 penelitian. Sedangkan di hari ke-2 dan ke-4 perlakuan pada kelompok kontrol, terdapat peningkatan rerata tekanan darah diastol, dan pada kelompok intervensi terjadi peningkatan rerata tekanan darah diastol di hari ke-3 dan ke-4.

2. Analisa Bivariat

a. Perbedaan Rata-Rata Tekanan Darah Sebelum (pretest) dan Sesudah (posttetst) Terapi Relaksasi Nafas Dalam dan Murottal

Tabel 2. Perbedaan Tekanan Darah Sebelum dan Sesudah Pemberian Terapi Relaksasi Nafas Dalam dan Murottal Di Posyandu Lansia Pisang Mas Pandak Bantul Yogyakarta

\begin{tabular}{lcc}
\hline \multirow{1}{*}{ Kelompok } & TD Pretest-Posttest & P value \\
\cline { 2 - 3 } & Mean \pm SD & \\
\hline Intervensi & $0,500 \pm 0,519$ & 0,003 \\
Kontrol & $0,692 \pm 0,751$ & 0,006 \\
\hline
\end{tabular}

Tabel 2 pengujian paired t-test yang didapatkan pada kelompok intervensi bahwa rerata tekanan darah sebelum dan sesudah perlakuan adalah 0,500 $\pm 0,519$ dengan hasil nilai $p$ value $0,003<0,05$. Berdasarkan pengujian tersebut, dapat diambil kesimpulan bahwa terdapat perbedaan tekanan darah antara sebelum dan sesudah pemberian terapi relaksasi nafas dalam dan murottal. Sedangkan pada kelompok kontrol, rerata tekanan darah sebelum dan sesudah perlakuan adalah $0,692 \pm 0,751$ dengan hasil nilai $p$ value $0,006<0,05$, dengan hasil pengujian ini, maka dapat diambil kesimpulan bahwa terdapat perbedaan tekanan darah sebelum dan sesudah pemberian terapi murottal.

b. Perbandingan Rerata Tekanan Darah Dengan Pemberian Terapi Murottal dan Kombinasi Terapi Relaksasi Nafas Dalam dan Murottal Di Posyandu Lansia Pisang Mas Pandak Bantul Yogyakarta

Tabel 3. Perbandingan Rerata Tekanan Darah Sistol dan Diastol dengan Pemberian Terapi Murottal dan Kombinasi Terapi Relaksasi Nafas Dalam dan Murottal Di Posyandu Lansia Pisang Mas Pandak Bantul Yogyakarta

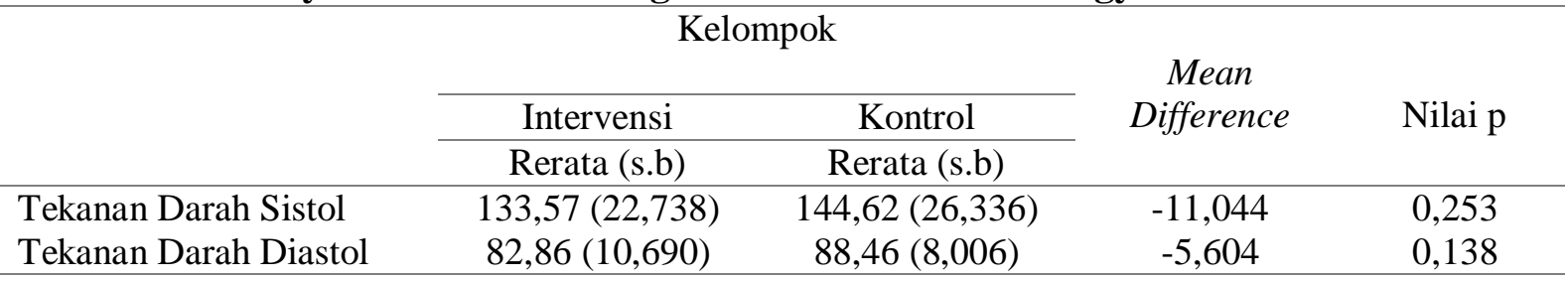

Tabel 3 Pengujian Independent t-test diketahui bahwa selisih tekanan darah sistol pada kedua kelompok adalah $p$ value 0,253>0,05. Berdasarkan pengujian tersebut, dapat disimpulkan bahwa tidak terdapat perbedaan rerata penurunan tekanan darah sistol antara yang diberikan kombinasi terap relaksasi nafas dalam dan murottal maupun yang hanya diberikan terapi murottal dengan selisih rerata penurunan lebih besar pada kelompok intervensi yaitu 133,57 dibandingkan dengan kelompok kontrol 144,62. Mean difference tekanan darah sistol kedua kelompok adalah -11,044. Sedangkan untuk selisih tekanan darah diastol pada kedua kelompok diketahui bahwa $p$ value $0,138>0,05$, dengan berdasarkan 
pengujian tersebut, maka diperoleh kesimpulan bahwa tidak terdapat perbedaan rerata tekanan darah diastol antara yang diberikan kombinasi terapi relaksasi nafas dalam dan murottal maupun yang hanya diberikan terapi murottal dengan selisih rerata penurunan lebih besar pada kelompok kontrol yaitu 88,46 dibandingkan dengan kelompok intervensi 82,86. Mean difference tekanan darah diastol kedua kelompok adalah -5,604.

\section{PEMBAHASAN}

1. Karakteristik Responden

Karatkteristik responden berdasarkan jenis kelamin, menunjukkan bahwa perempuan lebih dominan yaitu sebanyak 11 lansia $(78,6 \%)$ pada kelompok kombinasi relaksasi nafas dalam dan murottal dan 12 lansia $(92,3 \%)$ pada kelompok terapi murottal. Hal ini terjadi karena pada perempuan mengalami masa menopause. Hormon estrogen merupakan hormon yang berperan dalam kadar HDL (high density lipoprotein) seseorang yang mampu untuk melindungi dan mencegah dari penyakit arterosklerosis, hormon ini hanya dapat ditemukan pada perempuan saat mereka belum mengalami masa menopouse(8). Penelitian yang dilakukan oleh Nurhakim, A. I., Dewi, I. P., \& Rohmah, N. (2018) tentang pengaruh terapi Qur'anic healing terhadap penurunan tekanan darah pada lanjut usia penderita hipertensi, dimana lanjut usia yang berjenis kelamin perempuan lebih beresiko terkena penyakit hipertensi, karena pada saat itu, lanjut usia sudah memasuki masa menopause sehingga produksi hormon estrogen yang digunakan dalam perlindungan penyakit kardiovaskuler semakin berkurang, oleh sebab itu lanjut usia perempuan memiliki resiko yang lebih besar mengalami penyakit hipertensi jika dibandingkan dengan lanjut usia laki-laki(15). Penelitian yang dilakukan oleh Riamah, R. (2019), diketahui bahwa faktor-faktor penyebab terjadinya hipertensi pada lanjut usia di UPT PSTW khusnul khotimah yaitu jenis kelamin memiliki faktor yang lebih kuat terjadinya hipertensi(16). Perubahan hormon estrogen pada perempuan pada umumnya terjadi pada saat usia 45-55 tahun(8), setelah melewati batas ini, maka peningkatan tekanan darah pada lajut usia perempuan akan semakin terjadi, hingga pada saat lanjut usia berumur 75 tahun.

Usia adalah salah satu faktor resiko yang tidak dapat diubah. Saat usia sekitar 30-90 tahun massa jantung akan bertambah 1 gram/tahun pada pria dan 1,5 gram/tahun pada perempuan. Katup-katup jantung pun akan mengalami perubahan di usia yang semakin bertambah(17). Umur responden sebagian besar berada dalam rentan umur 60-70 tahun sejumlah 15 lansia. Penelitian yang dilakukan oleh Riamah, R. (2019) mengungkapkan bahwa, sebagian besar lanjut usia dalam penelitiannya berada dalam batas usia 60-74 tahun. Diketahui bahwa pada rentang usia tersebut, struktur tubuh khususnya pembuluh darah besar akan mengalami penyempitan sehingga dinding pembuluh darah besar akan mengalami kekakuan, pada saat itu pompa jantung akan semakin meningkat untuk mensuplai darah, sehingga terjadi peningkatan tekanan darah(16). Penelitian yang dilakukan oleh Riza, Y., Hayati, R., \& Setiawan, W. (2019) tentang analisis faktor yang berhubungan dengan kejadian hipertensi, diketahui bahwa faktor usia memiliki hubungan yang sangat erat dari adanya penyakit hipertensi, hal ini terjadi akibat perubahan fisiologis yang dialami seseorang, serta adanya penebalan dinding arteri akibat penumpukan zat kolagen yang tak terkendali pada lapisan otot, sehingga pembuluh darah akan menjadi sempit dan kaku, selain itu akan terjadi penurunan fungsi ginjal dalam aliran darah ginjal serta penurunan laju filtrasi glomerulus yang berakibat pada peningkatan tekanan darah(18).

Lanjut usia dalam penelitian ini, sebagian besar berada pada tingkat pendidikan tidak sekolah yaitu sebanyak 17 lansia dari total 27 lansia yang diteliti. Tingkat pendidikan akan mempengaruhi cara seseorang dalam menjaga status kesehatannya, karena pada saat seseorang memiliki tingkat pendidikan yang tinggi, maka tingkat pengetahuan yang dimiliki akan semakin banyak pula, begitupun sebaliknya. Lansia dengan pendidikan tidak sekolah 
akan memiliki cara meningkatkan kesehatan yang lebih rendah bila dibandingkan dengan lansia yang memiliki tingkat pendidikan sekolah(19). Dalam penelitian Riamah, R. (2019), didapatkan bahwa lansia dalam penelitiannya terbanyak memiliki tingkat pendidikan tidak sekolah. Penyakit hipertensi akan cenderung lebih tinggi pada lansia yang memiliki tingkat pengetahuan yang kurang akibat rendahnya tingkat pendidikan, namun hal tersebut akan semakin menurun jika lansia memiliki tingkat pengetahuan yang banyak dengan tingkat pendidikan yang tinggi. Hal ini akan berkaitan dengan cara lansia dalam meningkatkan atau menjaga status kesehatannya khususnya dalam tekanan darah(16).

Sementara itu, lamanya menderita hipertensi pada penelitian ini adalah 1-2 tahun, yaitu sebanyak 22 lansia dari total 27 lansia. Penelitian yang dilakukan oleh Nurhidayati, I., Aniswari, A. Y., Sulistyowati, A. D., \& Sutaryono, S. (2019) tentang penderita hipertensi dewasa lebih patuh daripada lansia dalam minum obat penurun tekanan darah. Dalam penelitiannya, responden terbanyak menderita hipertensi dalam waktu 1-2 tahun yang mengakibatkan terjadinya perubahan fisiologis jantung yaitu jantung akan mengalami pembesaran atau yang disebut dengan hipertrofi sebagai akibat dari adanya proses penuaan(20). Selain itu organ lain pula seperti pembuluh darah akan mengalami penyempitan, dinding pembuluh darah akan menebal, sehingga kekuatan otot jantung dalam memompa darah akan mengalami penurunan yang mengakibatkan seorang lansia memiliki resiko tinggi terkena penyakit jantung seperti hipertensi, gangguan irama jantung, bahkan mengalami jantung coroner(21).

2. Perbedaan Selisih Penurunan Rerata Tekanan Darah Sistolik dan Diastolik Pada Kelompok Kombinasi Relaksasi Nafas Dalam dan Murottal Dengan Kelompok Pemberian Terapi Murottal

Berdasarkan pada hasil pengujian Paired T-test, diketahui bahwa terdapat perbedaan tekanan darah saat sebelum dan sesudah diberikan terapi relaksasi nafas dalam dan murottal pada kelompok intervensi dengan hasil nilai $p$ value $0,003<0,05$. Begitu pula pada kelompok kontrol yang hanya mendapatkan terapi murottal saja, didapatkan bahwa nilai $p$ value $0,006<0,05$ yang artinya bahwa pemberian kombinasi terapi relaksasi nafas dalam dan murottal maupun pemberian terapi murottal saja dapat menurunkan tekanan darah. Dari hasil pengujian frekuensi tekanan darah diketahui bahwa lanjut usia pada kelompok yang mendapatkan terapi murottal, pada hari ke-3 dan ke-4 penelitian, tekanan darah lansia meningkat setelah diberikan terapi murottal, sedangkan lansia yang mendapatkan terapi relaksasi nafas dalam dan murottal pada hari ke-2 dan ke-4 penelitian, tekanan darah meningkat, hal ini bisa dikarenakan oleh banyaknya faktor perancu yang dapat mempengaruhi tekanan darah seseorang seperti, tingkat stess lansia, gaya hidup lansia, makanan serta minuman yang setiap hari dikonsumsi oleh lansia, dimana faktor-faktor tersebut tidak mampu dikendalikan oleh peneliti. Pengukuran selisih tekanan darah sistol terhadap kedua kelompok perlakuan didapatkan nilai $\mathrm{p}$ value $>0,05(0,253>0,05)$, sedangkan tekanan darah diastole didapatkan nilai $\mathrm{p}>0,05(0,138>0,05)$ sehingga dapat disimpulkan bahwa penurunan tekanan darah baik pada kelompok yang diberikan terapi relaksasi nafas dalam dan murottal maupun kelompok yang hanya diberikan terapi murottal saja tidak mengalami perbedaan.

Perlakuan yang diberikan baik kombinasi relaksasi nafas dalam dan murottal yang diberikan pada kelompok intervensi maupun hanya perlakuan terapi murottal yang diberikan pada kelompok kontrol, keduanya dapat digunakan dalam penurunan tekanan darah. Hal ini disebabkan mekanisme relaksasi nafas dalam adalah melakukan nafas dalam, dimana seseorang akan melakukan nafas lambat dengan menahan inspirasi secara maksimal kemudian menghembuskannya secara perlahan. Pernafasan yang dilakukan secara dalam dan perlahan akan memberikan energi pada saat kita menghembuskan nafas sehingga pengeluaran zat karbondioksida sebagai kotoran dari hasil pembakaran akan maksimal pula, dan saat kita akan 
kembali menarik nafas, maka kita akan mendapatkan oksigen yang diperlukan oleh tubuh dalam membersihkan darah serta menghasilkan kekuatan(22). Lantunan Al-Qur'an secara fisik mengandung unsur suara manusia, sedangkan suara manusia merupakan instrument penyembuhan yang menakjubkan. Suara memiliki efek positif yang banyak, dimana salah satunya adalah untuk menurunkan kadar hormon endorphin alami yang dapat meningkatkan perasaan rileks, penurunan rasa takut, cemas, tegang serta mampu memperbaiki sistem kimia tubuh yang berhubungan dengan pengontrolan tekanan darah, irama jantung, nadi, dan aktivitas gelombang otak(23). Relaksasi nafas dalam dengan atau tanpa terapi nonfarmakologis lainnya dapat memberikan pengaruh terhadap tekanan darah bagi yang mengaplikasikan terapi tersebut(24).

Penelitian ini didukung oleh penelitian yang dilakukan oleh Irfan, I., \& Nekada, C. D.Y. (2018) menyatakan bahwa terapi relaksasi nafas dalam dapat digunakan dalam perubahan tekanan darah lanjut usia yang mengalami hipertensi. Perubahan tekanan sistol dan diastol dalam penelitian ini dikarenakan adanya perlakuan yaitu relaksasi nafas dalam, dengan melakukan relaksasi nafas dalam, maka akan memaksimalkan oksigen yang masuk kedalam tubuh kita sehingga akan terjadi peregangan atau pelebaran pada kardiopulmonari, dimana stimulus peregangan ini akan sampai pada medulla oblongata yang dibantu oleh saraf vagus yang menyebabkan terjadinya peningkatan respon baroreseptor, kemudian impuls aferen akan melakukan fungsinya dengan meningkatkan aktivitas saraf parasimpatis dan akan menghambat saraf simpatis yang mengakibatkan vasodilatasi sistemik, dan terjadi penurunan denyut jantung dan kontraksi jantung(25).

Penelitian lain yang dilakukan oleh Wijayanti, S., \& Wulan, E. S. (2017), dimana dengan melakukan relaksasi selama 7 menit dapat menurunkan tekanan darah sistol dan diastol seseorang. Dengan melakukan relaksasi nafas dalam secara tenang dan rileks, maka akan mengakibatkan hipotalamus berespon dengan penurunan sekresi CRH (corticotropin releasing hormon) dan ACTH (adrenocorticrotophic hormon). Dari adanya penurunan kedua hormone ini, maka aktivitas saraf simpatis mengalami penurunan, dan pengeluaran adrenalin dan noradrenalin berkurang, sebagai akibatnya, maka akan terjadi penurunan tekanan denyut jantung, pelebaran pembuluh darah, tahanan yang berada dalam pembuluh darah berkurang, serta pompa jantung menurun yang akan mengakibatkan penurunan tekanan darah jantung arteri, dan terjadi perubahan tekanan darah pada seseorang (26).

Penelitian yang dilakukan oleh Aziza, C. N. (2019), dimana dalam penelitiannya untuk mengetahui pengaruh murottal Al-Qur'an baik dalam penanganan pengendalian emosi (anger management) maupun penurunan tekanan darah pada penderita hipertensi. Pemberian bacaan Al-Qur'an merupakan stimulus yang dapat diberikan kepada responden penderita hipertensi tanpa menimbulkan efek samping. Responden akan mendengarkan stimulus tersebut melalui audio yang akan menggetarkan genderang dan cairan telinga yang diperantai molekul Nitric Oxide yag terlibat dalam menggetarkan sel-sel rambut dikoklea(12). Dari saraf koklearis akan menuju keotak dan berada disepanjang thalamus hingga sampai pada korteks auditorik, pada saat inilah pusat emosi diaktifkan oleh sistem limbik, kemudian akan diteruskan pada hipokampus, mengantarkan sumber sinyal musik ke amigdala yang merupakan perilaku kesadaran bekerja dalam tingkat alam bawah sadar, kemudian akan berlanjut pada hipotalamus yang merupakan area pengaturan sebagian fungsi vegetative dan fungsi endorfin tubuh seperti halnya perilaku emosional. Jarak pendengaran akan berlanjut diornatio retikularis yag dijadikan sebagai penyalur impuls menuju serat otonom yang terdiri atas saraf simpatis dan parasimpatis, yang kemudian akan memberikan relaksasi terhadap organ-organ tubuh yang diatur oleh Nitric Oxide sebagai transmitter dan sebagai hormon yag bekerja dengan mengaktifkan guanylate cuclase yang dapat menyebabkan vasodilatasi dan relaksasi(27). 
Penelitian yang dilakukan oleh Hendriana, Y. (2016), diketahui bahwa surah ArRahman dapat berfungsi dalam penurunan tekanan darah pada penderita hipertensi di poskesdes kedungarum UPTD PKM kuningan kab. Kuningan Jawa Barat, dilaporkan bahwa lansia yang mengalami hipertensi setelah mendengarkan bacaan surat Ar-Rahman menyatakan bahwa mereka merasakan ketenangan dan juga merasa rileks, namun tidak semua lansia dapat merasakan hal tersebut, ada pula beberapa lansia yang mengatakan biasa-biasa saja setelah mendengarkan audio surat Ar-Rahman, namun secara keseluruhan terapi audio surat Ar-Rahman dapat dijadikan sebagai terapi tambahan yang mudah dijangkau serta tidak menimbulkan efek samping sama sekali dalam pengontrolan tekanan darah pada penderita hipertensi. Suara yang dihasilkan dari audio surat Ar-Rahman dapat menurunkan kadar hormon endorphine alami yang dapat meningkatkan perasaan rileks seseorang, mengurangi rasa cemas dan tegang, memperbaiki sistem kimia tubuh sehingga terjadi penurunan tekanan darah dan memperlambat pernafasan, detak jantung, denyut nadi serta aktivitas gelombang otak. Mendengarkan murottal Al-Qur'an yang memiliki efek secara keagamaan juga memiliki banyak manfaatnya seperti menimbulkan efek relaksasi dan distraksi. Mendengarkan murottal akan mempengaruhi sisi psikologis bagi pendengarnya, serta respon penerimaan dan kepasrahan terhadap sang maha Khaliq terhadap masalah hidup yang dianggap sebagai ancaman lebih baik dan cepat(23).

\section{SIMPULAN}

Dari penelitian ini diketahui bahwa terapi relaksasi nafas dalam dan murottal memiliki pengaruh dalam penurunan tekanan darah lansia yang menderita hipertensi dengan terjadi peningkatan tekanan darah pada hari ke-3 dan 4 penelitian. Selain itu terapi murottal tanpa adanya relaksasi nafas dalam juga dapat menurunkan tekanan darah lansia hipertensi denga terjadi peningkatan tekanan darah pada hari ke-2 dan 4 penelitian. Dari terapi tersebut, baik yang hanya diberikan murottal saja maupun yang diberikan kedua terapi sama-sama dapat menurunkan tekanan darah lansia hipertensi.

\section{SARAN}

Disarankan bagi kader Posyandu Lansia Pisang Mas Pandak Bantul Yogyakarta dapat memfasilitasi lansia dalam menerapkan terapi relaksasi nafas dalam dan murottal yang sangat mudah dilakukan dan terjangkau serta tidak menimbulkan efek apapun dalam pengontrolan tekanan darah.

\section{UCAPAN TERIMA KASIH}

Terlaksananya penelitian ini penulis mengucapkan terimakasih kepada kepala Dukuh Gunting, serta kader Posyandu Lansia Pisang Mas Padak Bantul Yogyakarta yang telah memfasilitasi dan membantu dalam pengumpulan data sehingga dapat berjalan dengan lancar serta penulis ucapkan terimakasih kepada pihak review artikel JKP yang ikut membantu dalam kelengkapan dan kelayakan artikel penelitian ini.

\section{DAFTAR PUSTAKA}

1. Riset Kesehatan Dasa.r badan penelitian dan pengembangan kesehatan. kementerian RI [Internet]. 2018; Available from: http://www.kesmas.kemkes.go.id/assets/upload/dir_519d41d8cd98f00/files/Hasilriskesdas-2018_1274.pdf

2. Black JM, Hawks JH. keperawatan medikal bedah, manajemen klinis hasil yang diharapkan. singapura: elsevier; 2014.

3. Kementerian Kesehatan RI. INFODATIN: pusat data dan informasi kesehatan RI lansia. 
2014;

4. Miller carol A. nursing for wellnes in older adults. 7th ed. china: wolters kluwer; 2015.

5. DIY dinas kesehatan. profil kesehatan tahun 2018 DIY. 2018;

6. Statistik badan pusat. statistik penduduk lanjut usia tahun 2018. 2018; Available from: https://www.bps.go.id/publication/download.html?nrbvfeve $=Z W W F K$ YmFiNjUwN2MwNj I5NGI3NGFkZjcx\&xzmn=aHR0cHM6Ly93d3cuYnBzLmdvLmlkL3B1YmxpY2F0aW9 uLzIwMTgvMTIvMjEvZWFkYmFiNjUwN2MwNjI5NGI3NGFkZjcxL3N0YXRpc3Rpa y1wZW5kdWR1ay1sYW5qdXQtdXNpYS0yMDE4Lmh0bWw\%3D\&twoadfnoa

7. Bantul dinas kesehatan kabupaten. profil kesehatan tahun 2018 kabupaten bantul. 2018;

8. Nuraini B. Risk Factors of Hypertension. J Major [Internet]. 2015;4(5):10-9. Available from: http://juke.kedokteran.unila.ac.id/index.php/majority/article/view/602/606

9. Dewi S, Familia. hidup bahagia dengan hipertensi. jakarta: A plus book; 2010.

10. Fitriani. Pengaruh Terapi Relaksasi Nafas Dalam Terhadap Tekanan Darah Pada Lansia Pringgolayan Rt VII Banguntapan Bantul Yogyakarta. STIKes Surya Global Yogyakarta; 2016.

11. Despitasari L, Afrizal, Umar M. Pengaruh Mendengarkan Al-Qur'an Terhadap Perubahan Tekanan Darah Pada Lansia Penderita Hipertensi Diwilayah Puskesmas Andalas Padang Tahun 2018. J Kesehat Mercusuar [Internet]. 2019;2(1):8. Available from: http://jurnal.mercubaktijaya.ac.id/index.php/mercusuar

12. Aziza choirina nur. pengaruh murottal al-qur'an terhadap pengendalian emosi (anger management) dan tekanan darah pada penderita hipertensi [Internet]. universitas airlangga surabaya; 2019. Available from: http://repository.unair.ac.id/84081/4/FKP.N. 46-19 Azi p.pdf

13. Agustin wahyu rima, Rosalina S, Ardiani nurul devi, Safitri W. pengaruh terapi relaksasi genggam jari dan nafas dalam terhadap penurunan tekanan darah pada penderita hipertensi diwilayah kerja puskesmas kartasura. J Kesehat kusuma husada [Internet]. 2019;10(1):108-44. Available http://jurnal.ukh.ac.id/index.php/JK/article/view/337/287

14. Syakir S. islamic hypnoparenting: mendidik anak masa kini ala Rasulullah. jakarta: PT. kawan pustaka; 2014.

15. Nurhakim AI, Dewi inggriane puspita, Nurohmah. Volume 5 | Nomor $1 \mid$ Juni 2018. J keperawatan 'Aisyiyah [Internet]. 2018;5(6):7-15. Available from: https://journal.stikesaisyiyahbandung.ac.id/index.php/jka/article/view/89/45

16. Riamah. MENARA Ilmu Vol. XIII No.5 April 2019. J Penelit dan Kaji Ilm menara ilmu Univ muhamadiyah sumatera barat. 2019;XIII(5):106-13.

17. Ratnawati E. asuhan keperawatan gerontik. yogyakarta: pustaka baru press; 2017.

18. Riza Y, Hayati R, Setiawan W. Analisis faktor yang berhubungan dengan kejadian hipertensi. J Ilm ilmu Kesehat [Internet]. 2019;5(2):235-43. Available from: http://journal.stikes-kapuasraya.ac.id/index.php/JIIK-WK/article/view/153

19. Notoatmodjo prof D soekidjo. promosi kesehatan global. jakarta: rineka cipta; 2013.

20. Nurhidayati I, Aniswari AY, Sulistyowati AD, Sutaryono S. Penderita Hipertensi Dewasa Lebih Patuh daripada Lansia dalam Minum Obat Penurun Tekanan Darah. J Kesehat Masy [Internet]. 2018;13(2):4-8. Available from: https://jurnal.unimus.ac.id/index.php/jkmi

21. Santoso S. kesehatan dan gizi. jakarta: rineka cipta; 2009.

22. Tetti S, Cecep E. Konsep dan Aplikasi Relaksasi Dalam Keperawatan Maternitas. Bandung: PT. Refika Aditama; 2015.

23. Hendriana Y. Artikel penelitian. Ef Ter audio murottal surah ar-rahman terhadap perubahan tekanan darah pada lansia dengan Hipertens di poskesdes kedungarum UPTD 
PKM kuningan kabupaten jawa barat [Internet]. 2016;5(1):63-72. Available from: https://jurnal.unai.edu/index.php/jsk/article/view/777/604

24. Potter P., Perry A. fundamental keperawatan. 7 buku 2. singapore: elsevier; 2010.

25. Irfan, Nekada CD. PELAYANAN SOSIAL TRESNA WERDHA UNIT ABIYOSO. J keperawatan respati yogyakarta [Internet]. 2018;5(2):354-9. Available from: http://nursingjurnal.respati.ac.id./index.php./JKRY/index

26. Wijayanti S, Wulan emma setiyo. pengaruh teknik relaksasi nafas dalam terhadap penurun tekanan darah pada pasien hipertensi di RSUD dr.loekmono hadi kudus. Pros HEFA [Internet]. 2017;(2581-2270):403-10. Available from: http://prosiding.stikescendekiautamakudus.ac.id/index.php/pros/article/view/277/57

27. Al-atsari I. thibbun nabawi bukan alternatif, shahih al-qur'an dan terjemahannya. 2011. 